\title{
Influence of Professional Commitment and Locus of Control on Whistleblowing Intensity with Ethical Sensitivity as Intervening Variable (Case Study at Public Accounting Firms in Makassar)
}

Muhtar*

Faculty of Economics Bosowa University, Makassar, 90245 Indonesia

DOI: $10.36348 / \mathrm{sb} .2019 . \mathrm{v} 05 \mathrm{i} 12.013$

| Received: 05.12.2019 | Accepted: 15.12.2019 | Published: 26.12.2019

*Corresponding author: Muhtar

Abstract

This research is to test the influence of professional commitment and locus of control on whistleblowing intensity through ethical sensitivity at Public Accounting Firms in Makassar. Data was obtained from 4 Public Accounting Firms in Makassar. Primary data was obtained through field research by distributing questionnaire/statement sheet to 31 respondents. Data analysis method was path analysis processed by SPSS-21 program. The research results show that professional commitment and locus of control have partial positive and significant effects on the ethical sensitivity. In addition, professional commitment has positive and significant effects on whistleblowing intensity, locus of control has positive yet insignificant effects on whistleblowing intensity, and ethical sensitivity has positive and significant effects on whistleblowing intensity. Meanwhile on the intervening variable, professional commitment and locus of control have partial effects on whistleblowing intensity through ethical sensitivity.

Keywords: Professional commitment, locus of control, ethical sensitivity, whistleblowing intensity.

Copyright @ 2019: This is an open-access article distributed under the terms of the Creative Commons Attribution license which permits unrestricted use, distribution, and reproduction in any medium for non-commercial use (NonCommercial, or CC-BY-NC) provided the original author and source are credited.

\section{INTRODUCTION}

Public accountant services are services required by business people to obtain services in order to meet the needs of stakeholders such as creditor, investor, and government agencies as users of financial statements which purpose is to prove the fairness of financial statements presented by a company through the implementation of audits conducted by independent auditors. In carrying out its profession, auditors are required to be able to detect and even reveal any fraud. This makes public accountants vulnerable to temptations and risks. Therefore, only a few people are interested in becoming an auditor. A public accountant can either be a treasure or a misfortune for a company.

Cases such as corruption, fraud, manipulation, money laundering and so forth dragged public accountants. The number of cases becomes the main factor that raises doubt about public accountant both in Indonesia and global. The global phenomenal case in the world of accounting is the Enron case in 2001. Enron is a leading company in the United States. Enron manipulated the figures of financial statements to cover corporate debt. Arthur Andersen Public Accounting Firm which is known to have handled Enron's financial statements for years was involved in the case. It appears that large companies also involving Public Accounting Firms in conducting fraud, whereas Public Accounting Firms have the duty to detect, prevent and reduce fraud.

The other case is whistleblowing, which was the collapse of the Worldcom Company. The company moved the expense account to the capital account, thereby increasing the revenue or profit. Worldcom was able to increase profits because the expense account was recorded lower while the capital account was recorded higher and the capitalization expense was presented as investment expense. However, it was noticed by Cynthia Cooper as its internal auditor. Cynthia discussed the matter to her chief financial officer, Scott Sullivan, and the corporate controller at that time, David F.Myers. The problem was reported to the head of the audit committee, Max Bobbitt. Then, Max asked KPMG (Klynveld Peat Marwick Goerdeler) as an external audit to conduct an investigation to make worldcom declared it bankrupt [1]. 
Fraud does not only occur in the Foreign Affairs; it has also contaminated Indonesia. The case of accounting violations occurring in Indonesia is exemplified by Bank Lippo's double reporting case in 2002. Prasetio, Sarwoko and Sandjaja Public Accounting Firms with Ruchjat Kosasih as the auditor were the parties involved in the case. One way to restore the reputation or positive image of an auditor is by increasing disclosure or whistleblowing actions of an auditor as a whistleblower. Whistleblowing is a great way to prevent and reduce fraud in various cases of accounting violations. According to near and Miceli [2] in Mesmer-Magnus and Viswesveran [3], whistleblowing is a reporting by employees and former employees regarding offenses, illegal or immoral actions to parties inside and outside the organization. Meanwhile, someone who commits whistleblowing is called a violation reporter or whistleblower [4].

Being a whistleblower is not an easy task. Normally, someone who comes from an internal organization will face an ethical dilemma in deciding whether to "blow the whistle" or keep it in hiding. Some see whistleblowers as traitors who violate the norms of organizational loyalty; others view whistleblowers as heroic protectors against values which are considered more important than loyalty to the organization $[5,6]$. Such conflicting point of views often makes whistleblower candidates in a dilemma of determining the attitude that eventually reduces the whistleblowing interest.

The higher a person's professional commitment, the higher the intention to conduct whistleblowing, as did Cynthia Cooper, Susno Duadji and Agus Condro in the above case. This is in line with Elias [7] in Joneta [8] who said that a person who is committed to his/her profession always believes and accepts his/her professional goals and is willing to make a meaningful effort on his/her profession.

According to Shaub [9] in Janitra [10], ethical sensitivity is the ability to find out the ethical problems that occur. Meanwhile, according to Midyarany and Kurnia [11], ethical sensitivity is a person's ability to realize the existence of ethical or moral values in making a decision. Furthermore, Armstrong [12] in Muttaqin [13] defined ethical sensitivity as the process of interpreting situations, taking on the role of how various actions will affect the parties concerned, imagining the chain of cause-effect events, and realizing that there is an ethical/moral problem. Ethical sensitivity is also influenced by several factors, one of which is the locus of control.

According to Midrayarany and Kurnia [11], locus of control is a person's perspective on an event whether he/she is capable or unable to control events that happen to him/her. In performing his/her duties, an auditor is influenced by the locus of control, which relates to the belief in fate, confidence, and the effort or hard work of the auditor himself/herself.

Based on the above background and phenomena, the writer is interested in researching the influence of professional commitment and locus of control on the intensity of whistleblowing with ethical sensitivity as intervening variable at public accounting firms in Makassar.

\section{LITERATURE REVIEW Theory of Planned Behavior}

Theory of Planned Behavior (TPB) is an extension of the Theory of Reasoned Action (TRA) developed by Icek Ajzen and Martin Fishbein in 1980. [14]. Ajzen and Fishbein developed TPB by adding construct that does not yet exist in TRA, which is the perceived behavioral control [14]. Theory of Planned Behavior aims to predict the intentions of individual behavior, as stated by Kreshastuti and Prastiwi [3]:

"Theory of Planned Behavior aims to predict and understand the impact of behavioral intention, identify strategies to change behavior and explain real human behavior."

Theory of planned behavior explicitly recognizes the possibility that not all behaviors are under full control, so that the concept of perceived behavioral control is added to deal with such behaviors [3].

According to Ajzen [14] in Theory of Planned Behavior, the main factor of behavior shown by an individual is the intention to display a certain behavior. Intention is an indication of how hard someone is trying or how much effort is being made to perform a behavior. Theory of Planned Behavior (TPB) predicts the individual's intention to engage in behavior at a particular time and place. In addition, according to Ajzen [14], Theory of Planned Behavior stated that the behavior of an individual is driven by a behavioral intention, which is a function of three determinants: individual's attitude towards behavior, subjective norms, and perceived behavior control.

\section{Professional Commitment}

Aranya et al. [14] in Bakri [15] define professional commitment as a love formed by an individual to his/her profession, including his/her beliefs, achievements, goals and values of a profession. Meanwhile, according to Nugraha [16]:

"Professional commitment requires an employee to uphold the applicable values and norms in accordance with existing professional 
standards, so that an auditor should act in a professional manner."

An auditor who upholds a commitment to professionalism will take precautions in having a certain attitude that is not in accordance with professional standards and try to prevent whistleblowing, or attempt to be professional in the case of violation that requires him/her to reveal the violation [16].

According to Elias [7] in Joneta [8], a person committed to his/her profession always believes and accepts his/her professional goals and is willing to make a meaningful effort on his/her profession. Furthermore, Larkin [17] in Joneta [8] stated that professional commitment is essentially a perception of a person's loyalty, determination, and hope guided by the system, values or norms that will lead the person to act in accordance with certain procedures in the effort to carry out duties with a high success rate.

\section{Locus of Control}

The concept of Locus of control was first proposed in 1966 by a social learning theorist, Rotter, who claimed that Locus of control is one of personality variables defined as individual beliefs about the ability to control his/her own destiny [18].

According to Spector 1983 in Joneta [8], Locus of control is defined as the general expectation that rewards, reinforcements or results in life are controlled either by their own actions (internalization) or by other forces (externalities). According to Hariani et al. [19] in Purnamasari et al. [20], locus of control is a perception of their control over their fate, selfconfidence and belief in self-efficacy.

According to Spector 1988 in Joneta [8], Locus of control can be distinguished into two, Internal and External. Individuals with internal locus of control believe that events are the results of their own behavior or actions. They also believe that their experience is controlled by their own abilities or efforts. In contrast, individuals with external locus of control perceive achievable success are controlled by their surroundings, they tend to believe that the events they are experiencing are destiny, fate, opportunity, or merely luck. Individuals with internal locus of control are more satisfied with their work than those with external locus of control [21].

\section{Ethical Sensitivity}

According to Shaub [9] in Janitra [10], ethical sensitivity is the ability to find out ethical problems that occur. Meanwhile, according to Midyarany and Kurnia [11] ethical sensitivity is a person's ability to realize the existence of ethical or moral values in making a decision. Furthermore, Armstrong [12] in Muttaqin [13] defined ethical sensitivity as the process of interpreting situations, taking on the role of how various actions will affect the parties concerned, imagining the chain of cause-effect events, and realizing that there is an ethical/moral problem. Factors influencing an accountant's ethical sensitivity are disclosed based on Hunt and Vitell's theory [18] in Yulianto [22]. In particular, the cultural environment of accountants (CPAs), personal experiences, industrial environments, and organizational environments are hypothesized to influence their ability to recognize ethical situations. While in Dickerson [23] study in Muttaqin [13], ethical sensitivity is influenced by several factors, including ethical orientation, professional commitment, organizational commitment, professional skepticism, environmental culture, codes of ethics and personal characters. Overall, research on the factors affecting ethical sensitivity quite diverse.

\section{Whistleblowing}

Micell and Near [2] in Taylor and Curtis [24] stated that whistleblowing is an action taken by a member or a former member of an organization, which is reporting illegal, unethical, or unauthorized activities to management. Furthermore, Tuanakotta [25] also defined whistleblowing as follows:

"Whistleblowing is the disclosure of acts of violation or disclosure of unlawful, unethical or immoral acts or other acts which may harm the organization or stakeholders, committed by an employee or the head of the organization to the head of other organization or agency capable of committing the violation."

Furthermore, Elias [7] in Joneta [8] added that whistleblowing occurs from the inside (internal) and outside (external). Internal whistleblowing occurs when an employee is aware of a fraud committed by another employee and then reports it to their supervisor. Meanwhile, external whistleblowing occurs when an employee is aware of a fraud committed by the company and then notifies the public because the fraud will harm the community. Someone who commits whistleblowing is called a violation reporter or whistleblower [4]. Mesmer-Magnus and Viswevaran [26] conducted a meta-analysis of 26 studies on whistleblowing and concluded that generally whistleblowers have a good performance, a higher education, the position of supervisor and a higher moral reasoning than inactive fraud supervisors.

\section{RESEARCH CONCEPTUAL FRAMEWORK}

Based on above description among variables, the conceptual framework underlying this research can be illustrated in Figure 1 as follows: 


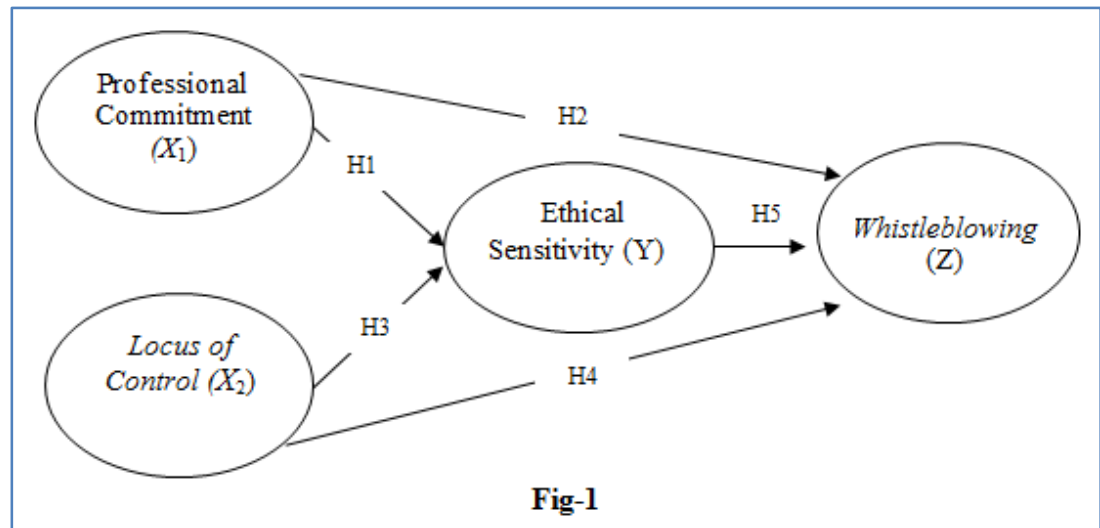

\section{RESEARCH MODELS}

\section{Research Hypotheses}

Based on research questions and theoretical review, the hypotheses of this research are as follows:

$\mathrm{H}_{1}=\quad$ It is alleged that professional commitment has a significant effect on ethical sensitivity.

$\mathrm{H}_{2}=$ It is alleged that auditor professional commitment has a significant effect on whistleblowing intensity.

$\mathrm{H}_{3}=$ D It is alleged that locus of control has a significant effect on ethical sensitivity.

$\mathrm{H}_{4}=$ It is alleged that locus of control has a significant effect on whistleblowing intensity.

$\mathrm{H}_{5}=\quad$ It is alleged that ethical sensitivity has an effect on whistleblowing intensity.

$\mathrm{H}_{6}=\quad$ It is alleged that professional commitment has an effect on whistleblowing intensity through ethical sensitivity.

$\mathrm{H}_{7}=\quad$ It is alleged that locus of control has an effect on whistleblowing intensity through ethical sensitivity.

\section{RESEARCH METHODS}

This research is quantitative because it is to determine the relationship between two or more variables by using primary data. Primary data is data collected by the researcher directly from the first source or research location [27]. Data collection method used in this study was the distribution of questionnaires. Questionnaire is a data collection technique that is done by providing a list of questions/statements to be filled by the respondents and they are asked to provide their opinions or answers to questions/statements by using Likert scale. This research was conducted at Public Accounting Firms in Makassar. The population in this research was all independent auditors working in public accounting firms registered at Indonesian Institute of Certified Public Accountants (IICPA) and located or working in Makassar. The reason behind the selection of auditors as the object of research was because the auditor is one of the professions in the field of accounting most likely to deal directly with the ethical dilemma when carrying out responsibilities in the work. The population and sample in the study are listed in the table below:

Table-1: List of Public Accounting Firms in Makassar

\begin{tabular}{|c|l|c|}
\hline No. & \multicolumn{1}{|c|}{ Public Accounting Firms } & Number of Auditors \\
\hline 1. & Benny, Tony, Frans \& Daniel Public Accounting Firm & 7 \\
\hline 2. & Drs. Harly Weku Public Accounting Firm & 7 \\
\hline 3. & Drs. Rusman Thoeng, M.Com, BAP Public Accounting Firm & 5 \\
\hline 4. & Drs. Thomas, Blasius, Widartono \& Rekan (Branch) Public Accounting Firm & 7 \\
\hline 5. & Usman \& Rekan (Branch) Public Accounting Firm & 13 \\
\hline 6. & Yakub Ratan Public Accounting Firm & 6 \\
\hline \multicolumn{2}{|c|}{ Total } & 45 \\
\hline
\end{tabular}

Source: Processed primary data (2017)

Table-2: List of Public Accounting Firm Samples in Makassar that became Respondents

\begin{tabular}{|l|l|c|}
\hline No. & \multicolumn{1}{|c|}{ Public Accounting Firms } & Number of Auditors \\
\hline 1. & Drs. Rusman Thoeng, M.Com, BAP Public Accounting Firm & 5 \\
\hline 2. & Drs. Thomas, Blasius, Widartono \& Rekan (Branch) Public Accounting Firm & 7 \\
\hline 3. & Usman \& Rekan (Branch) Public Accounting Firm & 13 \\
\hline 4. & Yakub Ratan Public Accounting Firm & 6 \\
\hline \multicolumn{2}{|c|}{ Total } & 31 \\
\hline
\end{tabular}

Source: Processed primary data (2017) 
This research used Partial Least Square (PLS) data analysis technique. PLS is a structural equation model (SEM) that is based on components or variants. According to Ghozali [28], PLS is an alternative approach that shifts from a covariance-based to variance-based SEM approach. In general, covariancebased SEM tests the causality or theory while PLS is more of a predictive model. PLS is a powerful analytical method [28], because it is not based on many assumptions. For example, data should be normally distributed and samples do not have to be large in number. In addition, it can be used to confirm the theory. PLS can also be used to explain the presence or absence of relationships between latent variables.

\section{RESEARCH RESULTS AND DISCUSSION Research Result}

Based on the results in Table 3 above, the direct and indirect effects are viewed from the $t$ statistical value and it is found that:

1. Professional Commitment (X1) positively and significantly influences Ethical Sensitivity (Y) with the significance value $(\mathrm{P})$ of $0.000<0.05$.

2. Professional Commitment (X1) positively and significantly influences whistleblowing intensity $(\mathrm{Z})$ with the significance value $(\mathrm{P})$ of $0.004<0.05$.

3. Locus of Control (X2) does not positively and significantly influences Ethical Sensitivity (Y) with the significance value $(\mathrm{P})$ of $0.259>0.05$.
4. Locus of Control (X2) does not positively and significantly influences whistleblowing intensity (Z) with the significance value $(\mathrm{P})$ of $0.423>0.05$.

5. Ethical Sensitivity (Y) positively and significantly influences whistleblowing intensity $(Z)$ with the significance value $(\mathrm{P})$ of $0.002<0.05$ and $\mathrm{T}_{\text {Count }}$ Value of 3.288. It is stated bigger than the $\mathrm{T}_{\text {table. }}$ Therefore, it can be assumed that the influence of Ethical Sensitivity variable (Y) on whistleblowing intensity (Z) by considering $\mathrm{T}$ count of 3.288 or $328.8 \%$.

6. Professional Commitment (X1) positively and significantly influences whistleblowing intensity (Z) through ethical sensitivity (Y) with the significance value $(\mathrm{P})$ of $0.005<0.05$, direct influence of 2.946, indirect influence of 2.815 and total influence of 5.761 .

7. Locus of Control (X2) does not positively and significantly influences whistleblowing intensity (Z) through ethical sensitivity (Y) with the direct incluence of 0.412 , indirect influence of 0.943 and total influence of 1.355. In addition, the influence of those three variables is not significant because the significance value $(\mathrm{P})$ is $0.346>0.05$ so the ethical sensitivity cannot mediate between locus of control and whistleblowing intensity.

Table-3: Hypotheses Test Based on Path Coefficient and Indirect Effect

\begin{tabular}{|c|c|c|c|c|c|c|c|}
\hline \multirow[b]{2}{*}{ HIP } & \multicolumn{3}{|c|}{ Variable } & \multirow{2}{*}{$\begin{array}{c}P \\
\text { Value }\end{array}$} & \multirow[b]{2}{*}{ Direct } & \multirow[b]{2}{*}{ Indirect } & \multirow[b]{2}{*}{ Desc. } \\
\hline & $\begin{array}{l}\text { Exogenous } \\
\text { Variable }\end{array}$ & $\begin{array}{c}\text { Intervening } \\
\text { Variable }\end{array}$ & $\begin{array}{l}\text { Endogenous } \\
\text { Variable }\end{array}$ & & & & \\
\hline 1 & $\begin{array}{l}\text { Professional } \\
\text { Commitment }\end{array}$ & & $\begin{array}{l}\text { Ethical } \\
\text { Sensitivity }\end{array}$ & 0,000 & 3,595 & - & Sig \\
\hline 2 & $\begin{array}{l}\text { Professional } \\
\text { Commitment }\end{array}$ & & $\begin{array}{l}\text { Whistleblowing } \\
\text { Intensity }\end{array}$ & 0,004 & 0,835 & - & Sig \\
\hline 3 & $\begin{array}{l}\text { Locus Of } \\
\text { Control }\end{array}$ & & \begin{tabular}{|l} 
Ethical \\
Sensitivity
\end{tabular} & 0,259 & 1,130 & - & $\begin{array}{l}\text { Not } \\
\text { Sig }\end{array}$ \\
\hline 4 & $\begin{array}{l}\text { Locus Of } \\
\text { Control }\end{array}$ & & $\begin{array}{l}\text { Whistleblowing } \\
\text { Intensity }\end{array}$ & 0,423 & 0,802 & - & $\begin{array}{l}\text { Not } \\
\text { Sig }\end{array}$ \\
\hline 5 & & $\begin{array}{l}\text { Ethical } \\
\text { Sensitivity }\end{array}$ & $\begin{array}{l}\text { Whistleblowing } \\
\text { Intensity }\end{array}$ & 0,002 & 3,073 & - & Sig \\
\hline 6 & $\begin{array}{l}\text { Professional } \\
\text { Commitment }\end{array}$ & $\begin{array}{l}\text { Ethical } \\
\text { Sensitivity }\end{array}$ & $\begin{array}{l}\text { Whistleblowing } \\
\text { Intensity }\end{array}$ & 0,005 & 0,835 & 2,815 & Sig \\
\hline 7 & $\begin{array}{l}\text { Locus Of } \\
\text { Control }\end{array}$ & \begin{tabular}{|l} 
Ethical \\
Sensitivity
\end{tabular} & $\begin{array}{l}\text { Whistleblowing } \\
\text { Intensity }\end{array}$ & 0,346 & 0,802 & 0.943 & $\begin{array}{l}\text { Not } \\
\text { Sig }\end{array}$ \\
\hline
\end{tabular}

Source: Processed Data (2017) 


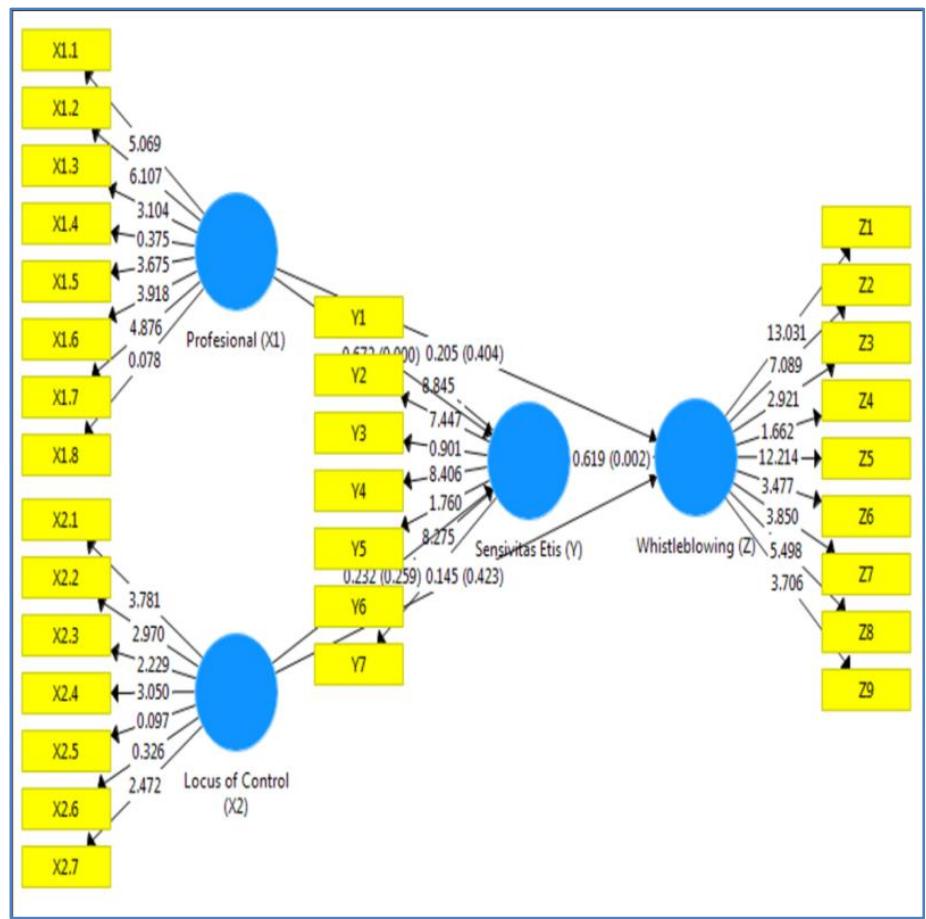

Fig-2: Path Analysis

\section{DISCUSSION}

\section{Influence of Professional Commitment on Ethical Sensitivity}

Hypothesis test results show that professional commitment has a positive and significant influence on ethical sensitivity. It means the higher the auditor's professional commitment, the higher his/her ethical sensitivity. The regression coefficient value marked positive indicates the unidirectional influence between professional commitment and ethical sensitivity means that if professional commitment increases, the auditor's ethical sensitivity will increase and vice versa. This is because the auditors at Public Accounting Firms in Makassar who have professional commitment must be able to face various pressures that may arise from within himself/herself or from external parties to maintain the reputation of his/her profession. Therefore, the commitment of auditor will affect ethical sensitivity because the higher the level of professional commitment, the higher the ability to understand the situation he/she faces, and vice versa. This research is in line with research conducted by Putri and Wahyuningsih [29] which suggested that professional commitment has a significant positive effect on auditor ethical sensitivity. Thus, $\mathrm{Ha}$ is accepted and $\mathrm{HO}$ is rejected.

\section{Influence of professional commitment on whistleblowing intensity}

Hypothesis test results show that professional commitment variable has a positive and significant influence on whistleblowing intensity. The regression coefficient value marked positive indicates the unidirectional influence between professional commitment and whistleblowing intensity means that if professional commitment increases, the auditor's whistleblowing intensity will increase and vice versa. An auditor with a high professional commitment will protect his profession from violations that leads to whistleblowing. This research is in line with research conducted by Joneta [8] and Bakri [15] who found that professional commitment has a positive effect on whistleblowing intention. Thus, $\mathrm{Ha}$ is accepted and $\mathrm{H} 0$ is rejected.

\section{Influence of locus of control on ethical sensitivity}

Hypothesis test results show that locus of control variable has no positive and significant influence on ethical sensitivity. This study is in contrast to research conducted by Iswarini and Mutmainah [19] which stated that locus of control has a significant positive influence on ethical sensitivity. However, this study is in line with research conducted by Sinaga [30] on influence of ethical reasoning, ethical orientation, and locus of control, gender and age on ethical sensitivity. The research shows that locus of control has no significant influence on ethical sensitivity. According Midyarany and Kurnia [11], locus of control is a person's perspective on an event whether he/she is capable or unable to control events that happen to $\mathrm{him} /$ her. In performing his/her duties, an auditor is influenced by the locus of control, which relates to the belief in fate, confidence, and the effort or hard work of the auditor himself/herself. However, this study failed to prove that locus of control has a significant influence on ethical sensitivity. This suggests that a good (right) choice of action is not directly determined by locus of control, but it is determined by the character of the 
auditor himself/herself and at the same time making decisions with tact, especially in relation to ethical issues faced in carrying out his/her duties. Thus, Ha is rejected and $\mathrm{H} 0$ is accepted.

\section{Influence of locus of control on whistleblowing intensity}

Hypothesis test results show that locus of control variable has no positive and significant influence on whistleblowing intensity. This study is in contrast to research conducted by Purnamasari et al. [20] who found that locus of control has a significance influence on whistleblowing. However, this study is in line with research conducted by Napitupulu dan Bernawati [31] who stated that locus of control has an insignificant influence on whistleblowing intensity.

Locus of control is related to the belief in the existence of destiny (fortune/luck), confidence, and effort or hard work of the auditor himself/herself. Factor of luck and fortune in work also does not affect the whistleblowing intensity of auditors. In this research, luck means income and work. Excellence in job or career, and the size of income does not have any influence on the auditor's intention to report the violation. The auditor shall work according to the applicable rules of conduct where they should disclose and report any alleged violation or offense, regardless of occupation, career and income. Thus, Ha is rejected and $\mathrm{HO}$ is accepted.

\section{Influence of ethical sensitivity on whistleblowing intensity}

Hypothesis test results show that ethical sensitivity variable has a positive and significant influence on whistleblowing intensity. The regression coefficient value marked positive indicates the unidirectional influence between ethical sensitivity and whistleblowing intensity means that if ethical sensitivity increases, the auditor's whistleblowing intensity will increase and vice versa. Ethical sensitivity is a person's ability to realize the existence of ethical or moral values in making a decision [11]. If an auditor has a high ethical sensitivity, he/she will tend to consider whistleblowing as an important action. Hence, his/her likelihood to do whistleblowing is higher.

This study is supported by research conducted by Janitra [10] and Yulianto [22] which stated that ethical sensitivity has a significant positive effect on whistleblowing intensity. Thus, $\mathrm{Ha}$ is accepted and $\mathrm{H} 0$ is rejected.

\section{Influence of professional commitment on whistleblowing intensity through ethical sensitivity \\ Ethical sensitivity in this study mediated relationship between professional commitment and whistleblowing intensity. The ethical sensitivity variable causes professional commitment variable}

affecting whistleblowing intensity in an indirect manner. This means that the more auditors obeys and runs his/her duties that have become a commitment to their profession, ethical decision made by that auditor will increase or he/she can make a better decision. An auditor who supports aims and values of his/her profession is implicitly more sensitive to the ethical situation and strives to focus more on the interests of the profession than on personal interests, or at least to view his/her own interests as a bind to his/her profession. Obviously, the auditor intends to maintain his/her professional membership and avoid ethical violations. Thus, an auditor with high professional commitment will be more sensitive to situations that may trigger whistleblowing.

This research is in accordance with the theory of planned behavior developed by Icek Ajzen and Martin Fishbein in 1980. In this theory, professional commitment represents attitude towards behavior. One of the attitudes of an auditor to demonstrate his/her professional commitment is through adherence to the Professional Standards for Certified Public Accountants and the Code of Ethics for Professional Public Accountants. Auditing standards and codes of conduct or rules of conduct that are made to be a guide in behaving especially in carrying out assignments in order to maintain the professional image. The higher the auditor's professional commitment, the higher his/her belief that whistleblowing is an important thing. Thus, $\mathrm{Ha}$ is accepted and $\mathrm{HO}$ is rejected.

\section{Influence of locus of control on whistleblowing intensity through ethical sensitivity}

In this research, ethical sensitivity does not mediate between locus of control and whistleblowing intensity at Public Accounting Firms in Makassar. According to Midyarany dan Kurnia [11], ethical sensitivity is a person's ability to realize the existence of ethical or moral values in making a decision. Indirect decision making is determined by locus of control and characteristics or personality of the auditor himself/herself. Moreover, the decision to do whistleblowing is not an easy task because of other factors such as fear of retaliation or consequences that will follow if from doing whistleblowing and whistleblower protection laws are not strict legislations. Thus, $\mathrm{Ha}$ is rejected and $\mathrm{HO}$ is accepted.

\section{CONCLUSION}

Research results show that professional commitment has a positive and significant influence on ethical sensitivity. The higher a person's professional commitment, the higher his/her ethical sensitivity. In other words, the more auditor obeys and runs his/her duties that has become a commitment to their profession, ethical decision made by that auditor will increase or he/she can make a better decision. Research results show that professional commitment has a 
positive and significant influence on whistleblowing intensity. That is, an auditor with a high professional commitment will protect his profession from violations by causing the intention to do whistleblowing. Research results show that locus of control does not have a positive and significant influence on ethical sensitivity. It means that the auditor's ethical sensitivity to the ethical situation that occurs around him/her is not influenced by the locus of control of an auditor. Research results show that locus of control does not have a positive and significant influence on whistleblowing intensity. It means that the auditor's tendency to do whistleblowing is not influenced by the level of locus of control of an auditor. Research results show that ethical sensitivity has a positive and significant influence on whistleblowing intensity. That is, if an auditor has a high sensitivity, he/she will tend to consider whistleblowing as an important action and it will increase his/her whistleblowing intensity. Research results show that professional commitment has a positive influence on whistleblowing intensity through ethical sensitivity. That is, an auditor with a high professional commitment will be more sensitive to situations that trigger whistleblowing. Research results show that locus of control does not have a positive and significant influence on whistleblowing intensity through ethical sensitivity. That is, even though an auditor's whistleblowing through ethical sensitivity is high, it remains unaffected by the auditor's locus of control. Thus, locus of control does not influence whistleblowing intensity either directly or indirectly.

\section{Suggestions}

1. Future researchers are suggested to expand the range of research by adding research samples as well as increasing the number of new variables in addition to variables used in this research to understand factors affecting whistleblowing intensity further.

2. In addition to questionnaires, further researchers are also suggested to use direct interview method to respondents so as to obtain more accurate information.

\section{REFERENCE}

\section{Farrel, Jamie.}

http://dokumen.tips/documents/kasus-skandal-

akuntansi-pada-worldcom.html retrieved on January 25, 2017.

2. Miceli, M. P., \& Near, J. P. (1985). Characteristics of organizational climate and perceived wrongdoing associated with whistle- blowing decisions. Personnel Psychology, 38(3), 525-544.

3. Kreshastuti, D. K., \& Prastiwi, A. (2014). Analysis of Factors Affecting Whistleblowing (Empirical Study of Public Accounting Firm in Semarang). Diponegoro Journal of Accounting, 3(2), 1-15.
4. Sagara, Y. (2013). Profesionalisme Internal Auditor Dan Intensi Melakukan Whistleblowing. Jurnal Liquidity, 2(1): 34-44.

5. Rothschild, J., \& Miethe, T. D. (1999). Whistleblower disclosures and management retaliation: The battle to control information about organization corruption. Work and occupations, 26(1), 107-128.

6. Bagustianto, Rizki and Nurkholis. 2015. Factors Affecting the Interest of Civil Servants (PNS) To Conduct Whistleblowing Actions (Studies in BPKRI PNS). Journal of Economics and Finance, 19(2): $276-295$.

7. Ridwan. (2008). Basic Statistics. Bandung : Alfabeta

8. Joneta, C. (2016). The Effect of Professional Commitment and Ethical Considerations on the Intention to Conduct Whistleblowing: Locus of Control as a Moderation Variable. JOM Fekon, 3(1): 734- 748 .

9. Shaub, M. K. (1989). An empirical examination of the determinants of auditors' ethical sensitivity (Doctoral dissertation, Texas Tech University).

10. Janitra, W.A. (2016). The Effect of Ethical Orientation, Professional Commitment, Organizational Commitment, and Ethical Sensitivity towards Internal Whistleblowing (Empirical Study on SKPD Pekanbaru City). JOM Fekon. 4(1): 1208-1223.

11. Midyarany, D., \& Kurnia. (2016). The Effect of Ethical, Gender Sensitivity, and Locus of Control on Student Ethical Behavior. STIESIA Surabaya ejournal: 1-17.

12. Armstrong, D. M. (2002). A materialist theory of the mind. Routledge.

13. Muttaqin, A.Z. (2014). Analysis of Factors Affecting the Ethical Sensitivity of Government Auditors. Essay. Diponegoro University Semarang.

14. Ajzen, I. (1991). The Theory of Planned Behavior. Organizational Behavior and Human Decision Processes 50: 179-210.

15. Bakri. (2014). Analysis of Professional Commitment and Anticipatory Socialization and Its Relationship with Whistleblowing. Al-Mizan Journal, 10(1): 152-167.

16. Nugraha, T. (2016). Effect of Professional Commitment, Ethical Environment, Machiavellian Nature and Personal Cost Against Whistleblowing Intentions With Retaliation As Moderating Variables (Empirical Study of Banking Companies Located In Pekanbaru City). JOM Fekon, 4(1): 2030- 2044.

17. Larkin, D. F., Kilvington, S., \& Easty, D. L. (1990). Contamination of contact lens storage cases by Acanthamoeba and bacteria. British Journal of Ophthalmology, 74(3), 133-135.

18. Badollahi, I. (2014). http://ismailbadollahi.blogspot.co.id/2014/03/artikel-auditing- 
locus-of-control.html retrieved on January 31, 2017

19. Iswarini, E.M., \& Siti, M. (2013). The Effect of Ethical Reasoning and Personal Factors on Ethical Sensitivity in Accounting Students. Diponegoro Journal of Accounting, 2(1): 1-11.

20. Purnamasari, D. (2016). The Effect of Ethical Sensitivity, Professional Identity, and Locus of Control on Whistleblowing Intention (Study of Accounting Students' Perception in Bandung). Proceedings of Accounting, 2(2): 955-963.

21. Curtis, M.B., \& E.Z. Taylor. (2009). Whistleblowing in Public Accounting Influence of Identity Disclosure, Situational Context and Personal Characteristics. Accounting and the Public Interest, 9(1): 191-220.

22. Yulianto, R., Dimas, A. (2015). The Influence of Ethical Orientation, Professional Commitment, and Ethical Sensitivity towards Whistleblowing (Empirical Study of the Supreme Audit Agency (BPK) Representative of Yogyakarta Special Region). Essay. Yogyakarta State University.

23. Dixon, L. B., Dickerson, F., Bellack, A. S., Bennett, M., Dickinson, D., Goldberg, R. W., \& Peer, J. (2009). The 2009 schizophrenia PORT psychosocial treatment recommendations and summary statements. Schizophrenia bulletin, 36(1), 48-70.

24. Taylor, E. Z., \& Curtis, M. B. (2010). An examination of the layers of workplace influences in ethical judgments: Whistleblowing likelihood and perseverance in public accounting. Journal of Business Ethics, 93(1), 21-37.

25. Tuanakotta, T.M. (2012). Forensic Accounting and Investigative Audit. Jakarta: Salemba Empat.

26. Mesmer-Magnus, J. R., \& Viswesvaran, C. (2005). Whistleblowing in organizations: An examination of correlates of whistleblowing intentions, actions, and retaliation. Journal of business ethics, 62(3), 277-297.

27. Siregar, S. (2013). Quantitative Research Methods. Jakarta: Prenanda Media Group.

28. Ghozali, I. (2009). Multivariate Analysis Application with SPSS Program. Edition Fourth. Diponegoro University Publisher.

29. Putri, D.E., Wahyuningsih. (2012). The Effect of Idealism, Relativism, Professional Commitment and Organizational Commitment on the Ethical Sensitivity of Auditors in BPKP Representatives of Riau Province. Journal of Economics, Management and Accounting, 18(1): 63-78

30. Sinaga, M.S. (2015). The Effect of Ethical Reasoning, Ethical Orientation, Locus of Control, Gender and Age on Ethical Sensitivity of Accounting Students. Essay. Diponegoro University Semarang.

31. Napitupulu, G.B., \& Bernawati, Y. (2016). The Effect of Organizational Factors, Individual Factors, and Demographic Factors on the Whistleblowing Intention. National Symposium on Accounting XIX, Lampung. 